\title{
PUSAT KOMUNITAS TUNANETRA KOTA BANJARMASIN
}

\author{
Rizki Maulina Sari \\ Program Studi Teknik Arsitektur Fakultas Teknik Universitas Lambung Mangkurat \\ h1b115027@mhs.ulm.ac.id
}

Muhammad Deddy Huzairin

Program Studi Teknik Arsitektur Fakultas Teknik Universitas Lambung Mangkurat deddyhuz@ulm.ac.id

\begin{abstract}
ABSTRAK
Sering kita jumpai penyandang tunanetra di tengah Kota Banjarmasin yang entah sedang meminta-minta, menjual koran, mengamen dengan alat musik walau terkadang menggunakan speaker dan alat tambahan lainnya atau menawarkan jasa pijat yang dilakukan dengan presentasi seadanya. Kenyataan yang baru saja dipaparkan merupakan salah satu keadaan yang menjadi sorotan dikarenakan kurangnya keragaman dalam pengembangan sumber daya manusia atau biasa disingkat SDM bagi para penyandang tunanetra. Beberapa penyebab menjadi alasan mengapa penyandang mengalami kesulitan dalam mengembangkan SDM pribadi sendiri, antara lain karena kurangnya fasilitas di ruang publik terutama untuk bermobilitas, ruang untuk berkembang baik untuk individu maupun kelompok juga dalam berorganisasi yang bisa membantu keteraturan dalam kegiatannya.

Analisis yang dilakukan awalnya berupa pengolahan beberapa metode yang juga didampingi dengan data berupa wawancara dan data dari pemerintah kota hingga akhirnya didapatkan satu metode yang paling tepat. Metode ini bertujuan untuk memberikan rangsangan pada individu berupa keaktifan, kenyaman serta kemampuan pengembangan diri pada penyandang tunanetra yang nantinya akan difokuskan pada landmark, clue, measurement dan compass direction. Pusat komunitas tunanetra ini diharapkan dapat menjadi tempat yang mampu membuat penyandang tunanetra merasa aman, nyaman dan berkeinginan untuk mengembangkan diri pribadi, bersosialisasi dan berorganisasi serta menjadi wadah edukasi bagi penyandang maupun non penyandang yang berkeinginan untuk memahami dan belajar lebih jauh
\end{abstract}

Kata kunci: pusat komunitas tunanetra, pengembangan diri, orientasi dan mobilitas, rangsangan individu.

\begin{abstract}
Oftentimes, we happen to meet with blind and visually impaired people in the middle of Banjarmasin City either while begging for some cash, tried to sell some newspaper, singing or more familiar with busking using musical instrument even though sometimes they also used speaker and any other additional instruments or offers massage service with a patch-up looking presentation. The reality that was just explained happen to be one of the situation where a lot of times were under spotlight due to the lack of diversity and also inclusivity in human resource development for blind and visually impaired people. Some of the reasons why difabel people struggled in developing the human resources inside individual is because the lack of facility in public spaces most likely in mobility side,
\end{abstract}


spaces for improvement for individual or also groups for doing organization that can help regularity within the activity inside.

Analysis was at first done by doing preparation and comparation between some methods which also includes data from interviews that already done before and also data from the city government until one best metode was concluded that in wish for to solve the problem that we are facing. This metode happen to have goals where it gives stimulation and excitement towards individual whether it is the feeling of being active, comfort, also the ability of self improvement that later on will be focused on some points which are landmark, clue, measurement and compass direction. This community center for blind and visually impaired people is expected to be the place that is competent enough to give difable people the feel of safeness, comfort and willingness of self improvement, socializing and doing organization also education spaces for difable and non difabel who is willing to learn more.

Keywords: community center for blind and visually impaired, self improvement, orientation and mobility, individual stimulation.

\section{PENDAHULUAN}

Sekarang ini ada banyak istilah yang biasa digunakan di masyarakat dalam menyebutkan penyandang difabel, salah satunya yaitu disabilitas atau tepatnya difabilitas. Istilah difabilitas merupakan penyebutan yang diperbarui dari kata disabilitas. Dipopulerkan di Kota Yogyakarta sejak tahun 1998 dan digunakan untuk menggantikan kata disabilitas, kata difabilitas juga merupakan bentuk kritik terhadap definisi health atau berarti sehat dalam Bahasa Indonesia yang sebelumnya dikeluarkan oleh WHO lebih dari 60 tahun yang lalu dan dipahami sebagai kondisi manusia dengan fisik, mental dan sosial yang lengkap dan juga tidak memiliki penyakit atau dalam kondisi lemah. Kata lengkap yang tertera di sana lantas menuai kritik karena kesehatan seseorang tentu tidak bisa ditentukan dengan waktu, dan pemahaman kata yang dicantumkan oleh WHO menekankan bahwa keadaan sehat ini akan berlangsung dalam jangka panjang. Konteks disabilitas ini sendiri masih sering dikaitkan dengan konotasi negatif karena makna awal disabilitas ini sendiri didapat dari dua suku kata "dis" yang berarti tidak dan "ability" yang berarti mampu, menekankan bahwa disabilitas berarti orang yang memiliki ketidakmampuan akan melakukan suatu hal dan lainnya. Oleh karena itu, kata disabilitas diganti menjadi kata difabilitas yang lebih akurat juga dapat menjelaskan keadaan maupun kekurangan seseorang secara lebih sopan.
Salah satu kelompok dari difabilitas yang disebutkan di atas, keterbatasan visual atau lebih akrab dikenal dengan tunanetra, tidak sedikit dapat kita jumpai di jalan raya besar. Beberapa dapat ditemui sedang berjalan kaki menggunakan tongkatnya ataupun sambil menggandeng seseorang, beberapa juga dapat ditemui dengan duduk di pinggir trotoar di tengah terik matahari, sambil biasanya menggunakan kertas yang sengaja digantung di leher, bertuliskan "terima pijat" ataupun "jasa pijat" beserta nomor telepon yang tertera di bawahnya. Hal ini merupakan hal yang lumrah namun sangat memprihatinkan karena sebagian besar tunanetra tersebut tidak memiliki pekerjaan tetap. Sesuai dengan survey di atas, penyandang difabilitas cenderung mendapatkan diskriminasi dalam mencari pekerjaan dan tidak seluruhnya memiliki keterampilan diri untuk bisa membuka usahanya sendiri. Untuk tunanetra, sebagian dari mereka yang sempat mengenyam pendidikan dan berhasil mengembangkan keterampilan memijat, biasanya memilih menjadi tukang pijat keliling di kota yang didiaminya.

Padahal, kehilangan fungsi visual tidak sedikitpun mengurangi kemampuan diri mereka, salah satunya adalah kemampuan berorganisasi. Hal ini dibuktikan dengan adanya organisasi yang dibuat negara demi meningkatkan kesejahteraan, kesamaan dan kesetaraan pada berbagai jenjang baik dari masyarakat, pemerintah juga pihak-pihak terkait. Tidak hanya itu, organisasi ini juga bertujuan untuk meningkatkan kemampuan 
diri penyandang tunanetra sehingga berdaya dari segi SDM. Organisasi ini bernama PERTUNI atau Persatuan Tunanetra Indonesia. Potensi untuk mengembangkan sumber daya atau keterampilan diri juga sangatlah tinggi baik untuk keterampilan kerajinan tangan, memijat, maupun kesenian ataupun musik.

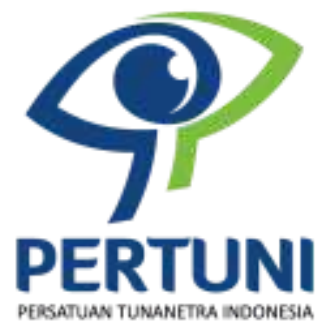

\section{Gambar 1. Logo Organisasi Pertuni Sumber: PERTUNI.or.id}

Kehilangan kemampuan visual memaksa penyandang memaksimalkan indera-indera lainnya terutama indera pendengaran, penciuman juga peraba untuk beraktivitas sehari-hari maupun bernavigasi antar satu tempat ke tempat lainnya. Kasus yang terjadi pada penyandang difabilitas netra sejak lahir, tentu mereka akan lebih mudah untuk beradaptasi dengan lingkungan sekitarnya, namun jauh berbeda dengan penyandang difabilitas netra semenjak remaja maupun dewasa, tentu akan ada kendala tambahan dimana penyandang diharuskan beradaptasi dengan kemampuan visual yang sebelumnya dimiliki dan kemudian menghilang. Ini menjadi faktor tambahan mengapa diperlukan fasilitas untuk pengembangan diri, memberikan wadah bagi penyandang difabilitas netra yang tidak sejak lahir dapat melatih diri.

Kemampuan tunanetra menjadi aspek utama dalam merancang bangunan yang memenuhi fasilitas yang diperlukan, dan pusat komunitas menjadi tempat yang diharapkan nantinya dapat membantu individu menjadi terampil, aktif dalam komunitas dan organisasinya, juga mampu beradaptasi dan mengembangkan diri di lingkungan yang mendukung dengan memaksimalkan kemampuan tunanetra yang akan dipahami dari perilaku, kebutuhan ruang juga lingkungan yang akan dipilih.

\section{PERMASALAHAN}

Permasalahan pada rancangan yang akan dihadapi adalah bagaimana rancangan pusat komunitas tunanetra di Kota Banjarmasin yang merangsang kemandirian, keaktifan, kenyamanan dan kemampuan diri penyandang.

\section{TINJAUAN PUSTAKA}

\section{A. Tinjauan Arsitektural}

\section{Tinjauan Tunanetra}

Banyak istilah yang digunakan orang awam untuk menyebutkan difabilitas netra, antara lain adalah buta, cacat mata, penderita buta, penderita cacat mata, penderita tunanetra, dalam bahasa inggris ataupun dalam literatur yang menjelaskan tentang tunanetra, juga menyebutkan banyak kosakata yang merujuk pada tunanetra antara lain seperti blind, totally blind, low vision, partially sighted, partially blind namun, literatur asing terbaru cenderung menggunakan kata visually impairment sebagai kata yang dipilih untuk menyebutkan tunanetra.

Tunanetra sendiri menurut Daniel $P$. Hallahan, James M. Kauffman dan Paige C. Pullen (2009: 380), dijelaskan dengan "Legally blind is a person who has visual acuity of 20/200 or less in the better eye even with correction (e.g., eyeglasses) or has a field of vision so sorrow that its widest diameter subtends an angular distance no greater than 20 degrees". Definisi di atas menjabarkan bahwa individu yang mengalami kebutaan merupakan individu yang ketajaman visualnya hanya mencapai $20 / 200$ atau bahkan kurang pada mata/penglihatan yang lebih baik walau sudah menggunakan perbaikan (semisal kacamata) atau memiliki penglihatan yang sangat sempit, yang lebar sudut pandangnya tidak lebih dari 20 derajat. 


\section{Tinjauan PERTUNI}

PERTUNI merupakan singkatan dari Persatuan Tunanetra Indonesia, sebuah organisasi kemasyarakatan tunanetra yang didirikan tahun 1966 oleh sekelompok penyandang tunanetra yang berada di Kota Solo. Beranggotakan anggota biasa atau para penyandang, mitra bakti yang tidak lain adalah individu yang tidak memiliki difabilitas namun bersuka rela mau membantu organisasi, hingga anggota kehormatan. Organisasi ini merupakan organisasi tingkat nasional yang memiliki tujuan maupun visi misi untuk mewujudkan keadaan kondusif bagi tunanetra untuk menjalankan kehidupannya sebagai manusia dan warga negara Indonesia yang cerdas. Disini, PERTUNI bertindak sebagai pengelola pusat komunitas. Berdasarkan lokasi dan kebutuhan pusat komunitas yang ditujukan untuk Kota Banjarmasin, oleh karena itu, sengaja ditunjuk PERTUNI tingkat cabang di wilayah Kota Banjarmasin sebagai pengelolanya.

\section{Tinjauan Pusat Komunitas}

Berdasarkan Kamus Besar Bahasa Indonesia, Pusat Komunitas merupakan tempat atau lokasi publik di mana anggota komunitas cenderung berkumpul untuk kegiatan berkelompok, dukungan sosial, informasi politik, dan kelompok khusus lainnya. Mereka kadang-kadang terbuka untuk seluruh masyarakat atau untuk kelompok khusus untuk masyarakat yang lebih besar. Pusat Komunitas dapat dibentuk dari 3 komponen, yaitu:

1. Berdasarkan lokasi / tempat, dalam komponen ini sebuah komunitas dapat terbentuk karena adanya interaksi di antara beberapa orang / kelompok yang tinggal di wilayah yang sama.

2. Berdasarkan minat, komunitas dapat terbentuk karena adanya interaksi orang-orang yang memiliki minat yang sama pada satu bidang tertentu.

3. Berdasarkan komuni, komunitas ini adalah komunitas yang terbentuk berdasarkan ide-ide tertentu yang menjadi landasan dari komunitas itu sendiri.

\section{B. Tinjauan Konsep}

1. Mobilitas dan Orientasi

Lowenfeld (1981) menyatakan, "Mobility which is the capacity or facility of movement has two component. One is mental orientation and the other is physical locomotion. Mental orientation has been defined as the ability of an individual to recognize his surroundings and their temporal or spatial relations to himself, and locomotion as the movement of an organism from place to place by means of its organic mechanism", sedangkan orientasi menurut Lowenfeld dalam Purwanta HK (1987) adalah suatu proses penggunaan semua indera yang masih ada untuk menentukan posisi seseorang terhadap benda-benda penting yang ada di sekitarnya.

Berdasarkan pengertian di atas, didapatkan bahwa mobilitas dan orientasi adalah kemampuan untuk berpindah dari satu tempat lainnya dengan menggunakan indera lain yang masih berguna yang dimiliki seorang individu untuk menentukan letak atau posisi seseorang terhadap benda-benda penting yang ada di sekitarnya.

Mobilitas dan Orientasi memiliki prinsip-prinsip yang selalu digunakan dengan menjawab pertanyaan tentang:

- Where am I? (Dimana saya berada?)

- Where is my objective? (Kemana tujuan saya?)

- How do I get there? (Bagaimana agar saya sampai di sana?)

Oleh karena itu, mobilitas dan orientasi dari beberapa komponen khusus yang berfungsi untuk menunjang gerak dan kerja tunanetra, antara lain:

\section{Landmark}

Elemen dengan karakteristik yang sudah diatur sehingga individu dapat 
membedakan lokasi satu dengan lokasi yang lainnya.

2. Clue

Merupakan rangsangan berupa visual, taktual, bau, temperatur (suhu) juga rangsangan auditorium (bunyi//suara) yang bertujuan untuk memaksimalkan kerja indera sehingga informasi yang didapat dijadikan petunjuk untuk menetapkan posisi dari individu dengan benda maupun dengan suatu garis arah.

\section{Measurement}

Adalah proses untuk mengukur suatu benda untuk mengetahui dimensi, bentuk, ukuran secara akurat dari suatu objek menggunakan ukuran yang sebelumnya sudah ditentukan.

\section{Compass Direction}

Merupakan arah khusus yang diatur sedemikian rupa untuk menunjukan posisi mengenai suatu objek.

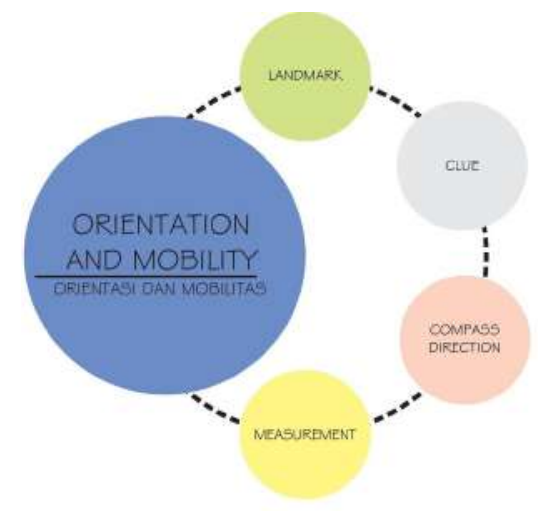

Gambar 2. Skema Orientasi dan Mobilitas Sumber: Analisis Pribadi (2020)

\section{PEMBAHASAN}

\section{A. Lokasi}

Tapak yang dipilih berlokasi di Belitung, yaitu tepatnya di Jalan Belitung Darat, Kecamatan Banjarmasin Timur. Tapak sengaja dipilih dengan beberapa pertimbangantermasuk lokasinya yang berada di pusat kota dengan kepadatan bangunan yang lumayan tinggi namun masih jauh dari kata padat, memiliki jalan yang sudah beraspal dengan lebar kurang lebih mencapai $15 \mathrm{~m}$, sirkulasi dapat diatur sehingga dapat mempermudah akses pencapaian menuju dan keluar tapak.

Kondisi tapak sendiri sebagian besar didominasi oleh bangunan perdagangan dan jasa sesuai dengan peraturan daerah yang mengatur area Belitung sebagai area perdagangan dan jasa. Sebagian besar bangunan terisi oleh rumah warga yang juga memiliki fungsi sebagai wadah dagang dan ruko dengan ketinggian dua hingga tiga lantai. Data tapak yang lebih lengkap dijelaskan sebagai berikut.

- Lokasi Lahan : Jalan Belitung Darat

- Status Lahan : Lahan Kosong

- Luas Lahan : $\pm 7600 \mathrm{~m}^{2}$

- GSB : $12 \mathrm{~m}$

- KDB : Maks $80 \%$

- KLB : :1-7

- Lebar Jalan : 15m

\section{Batasan Lahan:}

- Sisi Utara Tapak : Rawa

- Sisi Selatan Tapak : Rumah Warga

- Sisi Timur Tapak : Rumah dan Warung

- Sisi Barat Tapak : Ruko

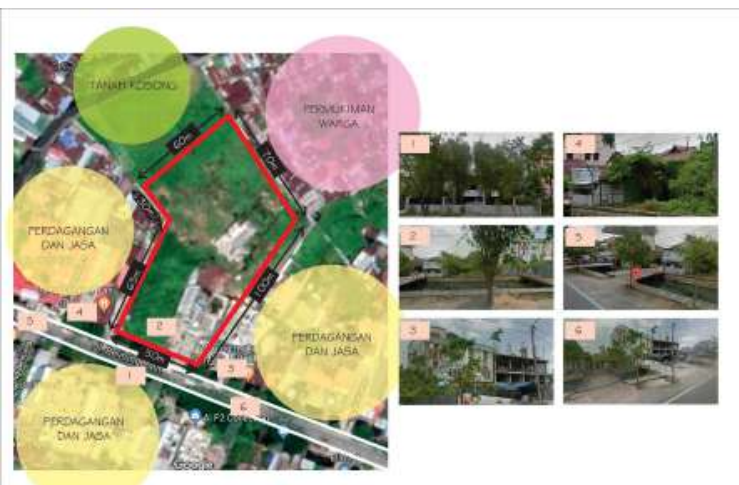

Gambar 3. Eksisting Tapak

Sumber: Analisis Pribadi (2020) 


\section{B. Konsep Rancangan}

\section{Tata Masa}

Tata masa di dalam kawasan, diatur dengan mempertimbangkan kenyamanan, keamanan, serta kemudahan dalam berorientasi di dalam ruang bagi penyandang tunanetra. Untuk itu, diperlukan penyesuaian terhadap kemampuan dan perilaku penyandang dalam mencapai antar ruang di dalam pusat komunitas.

Peletakkan dasar dari tata letak bangunan berdasarkan prinsip yang menggunakan pola yang mengikuti bentuk tapak dimana pergerakan individu di dalam area pusat komunitas diarahkan antar satu bangunan ke bangunan lainnya menggunakan indera selain indera penglihatannya. Indera-indera tersebut adalah indera penciuman, peraba hingga pendengaran dengan bantuan alat-alat semiotik di sekitar bangunan.

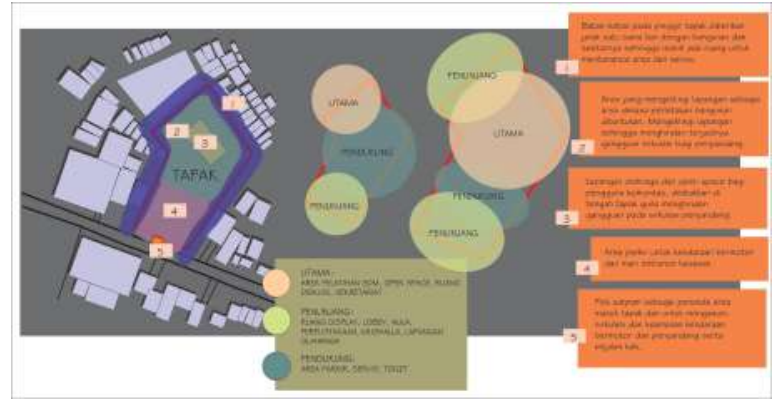

Gambar 4. Tata Masa di Dalam Kawasan Sumber: Analisis Penulis (2020)

\section{Masa Bangunan}

Masa bangunan diatur dari pola yang awalnya dibentuk dari pemahaman pola perilaku penyandang tunanetra, yang sebelumnya sudah diatur sedemikian rupa sehingga dapat membantu individu bermobilitas serta berorientasi dari satu bangunan ke bangunan lainnya, dengan bangunan yang memiliki ciri masing-masing, baik secara zona hingga perletakan. Massa bangunan yang digunakan pada pusat komunitas merupakan massa banyak dengan penggunaan pola yang mengikuti bentuk tapak sebagai pola yang membantu sirkulasi di dalam bangunan bagi penyandang tunanetra.

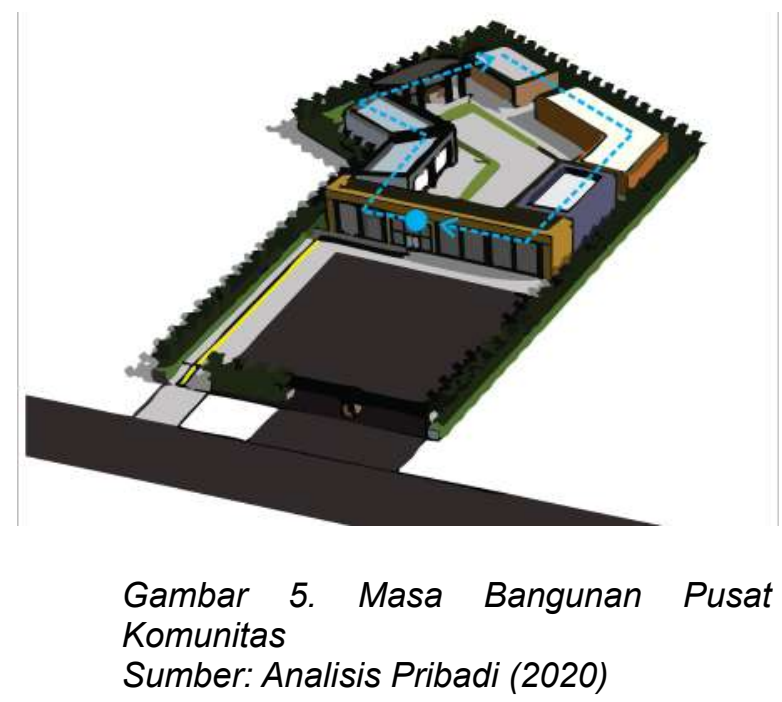

\section{Zoning}

Zoning atau zonasi pada tapak, diatur berdasarkan fungsi dan kebutuhan massa bangunan yang nantinya dibagi menjadi tiga zonasi yaitu zonasi utama, zonasi penunjang serta zonasi pendukung. Pada area depan tapak sengaja difungsikan sebagai bangunan penerima bagi pengunjung juga untuk penyandang.

Peletakan zonasi ini juga mempertimbangkan kebisingan, dan kebutuhan pencapaian, dimana untuk bangunan servis yang cenderung ribut, diletakkan di sisi paling belakang, guna mengurangi bising saat kegiatan berorganisasi maupun pengembangan sdm berlangsung di kawasan. 


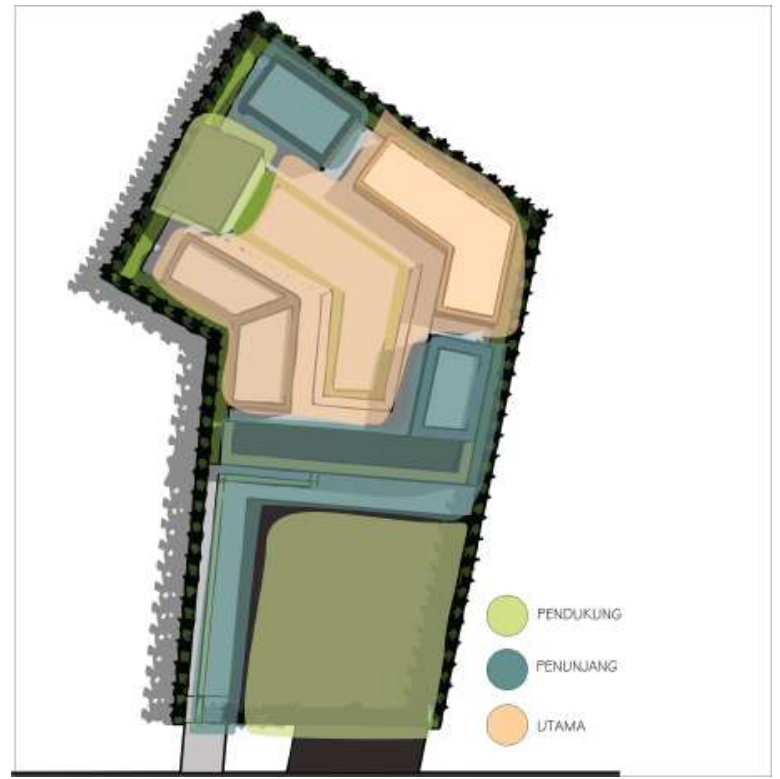

Gambar 6. Zoning Kawasan Pusat Komunitas

Sumber: Analisis Pribadi (2020)

\section{Block Plan}

Gambar di bawah adalah Block Plan bangunan dengan keterangan yang sudah dicantumkan di dalamnya.

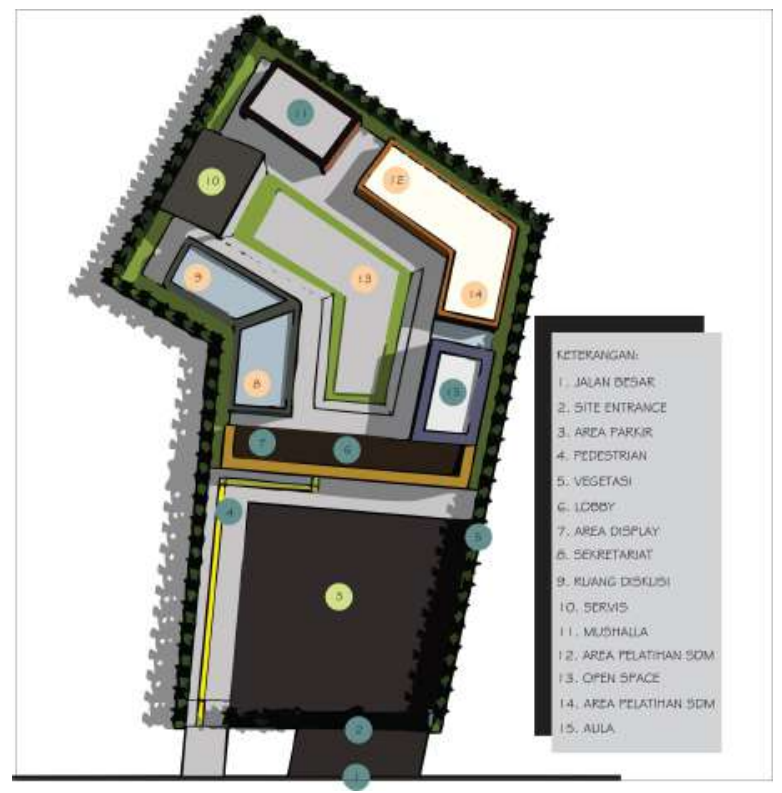

Gambar 7. Block Plan Kawasan Pusat Komunitas

Sumber: Analisis Pribadi (2020)

\section{Konsep Ruang}

Konsep ruang didesain sedemikian rupa guna membantu psikis pengguna baik penyandang maupun yang bukan penyandang, mengingat tujuan perancangan yang mengutamakan kenyamanan, keaktifan, kemandirian yang diharapkan bisa membantu pengembangan diri pada pengguna, tidak hanya untuk penyandang netra sejak lahir namun juga penyandang netra saat dewasa.

Desain ruangan disesuaikan berdasarkan kebutuhan juga fungsi, dengan harapan hasil akhir yang sama satu sama lainnya antar pengguna, tidak membeda-bedakan progress antar individu walau desain ruangan dibuat secara berbeda antar satu ruang dengan lainnya guna memaksimalkan keaktifan dan kemandirian diri penyandang dalam membedakan ruang satu dengan lainnya.

Penggunaan aroma-aroma tertentu juga menjadi bagian konsep ruang baik penggunaan aroma alami berupa vegetasi pada tapak, maupun buatan di dalam ruangan yang juga akan membantu sensitivitas indera penciuman dan diharapkan dapat membantu gerak penyandang terutama pada penyandang low vision.

\section{Konsep Area Luar}

Area luar kawasan sengaja diberikan ciri yang berbeda dengan lingkungan sekitarnya, termasuk dengan penggunaan landmark pada site entrance berupa signage sehingga dapat diingat dan dihafal bagi non penyandang baik itu pengguna maupun warga sekitar. 


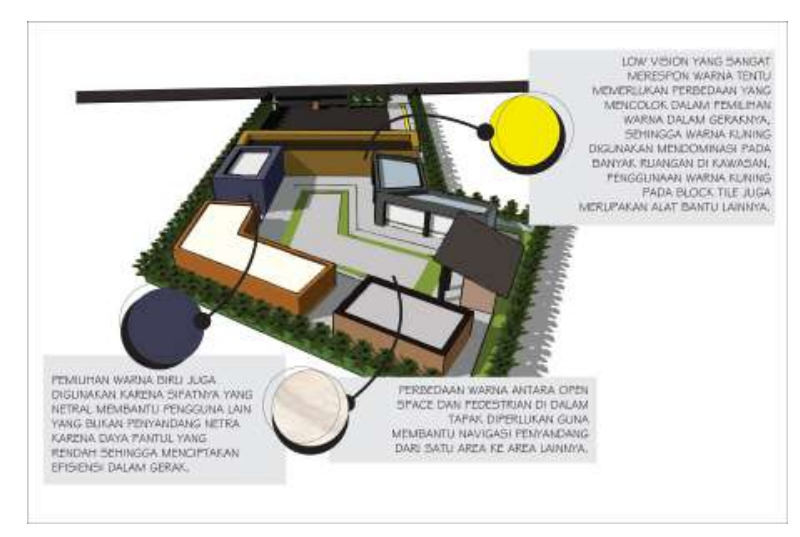

Gambar 8. Penggunaan Warna Pada Pusat Komunitas

Sumber: Analisis Pribadi (2020)

Pemilihan warna merupakan salah satu komponen paling penting dalam desain, penggunaan warna yang sesuai pada sebuah ruang membantu psikis pengguna terutama bagi penyandang low vision yang sangat merespon warna sehingga memerlukan perbedaan warna yang mencolok guna membantu pergerakannya, sehingga beberapa warna mencolok seperti kuning, hijau, dan merah akan mendominasi pada bangunan dan ruangan di dalam kawasan. Penggunaan warna ini tidak hanya akan diaplikasikan pada warna cat, namun juga alat bantu lainnya seperti block tile yang sengaja dipilih dengan warna kuning mencolok.

Penggunaan vegetasi pada tapak juga jadi pertimbangan karena bisa memberikan peran besar dalam wayfinding bagi penyandang dengan mengandalkan indera penciuman, maka sesuai penjelasan pada gambar di bawah ini ada beberapa tanaman yang nantinya akan ditanam pada kawasan dengan harapan tak hanya memberikan kesan hias juga memberikan peneduh namun juga wangi-wangian yang berbeda di satu area dengan area lainnya.

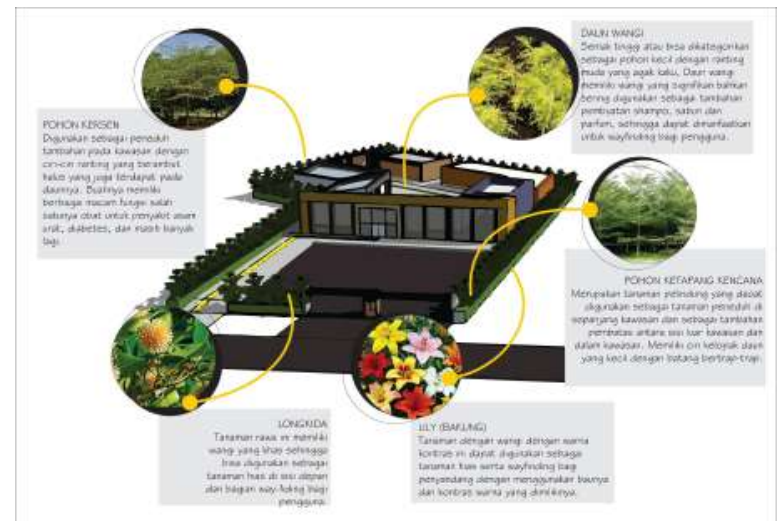

Gambar 9. Vegetasi Pada Kawasan Pusat Komunitas

Sumber: Analisis Pribadi (2020)

\section{HASIL}

Pusat Komunitas merupakan wadah untuk berkumpul, beraktivitas sebuah organisasi, komuni, maupun perkumpulan dengan ruang yang diisi sesuai dengan kebutuhan para penggunanya dan fokus gerak pengguna yang mengarah kemana. Untuk kasus ini pusat komunitas berfokus untuk pengembangan SDM, yang meningkatkan keaktifan, kemandirian, kenyamanan dan kemampuan diri penyandang difabilitas netra, baik itu buta total maupun low vision.

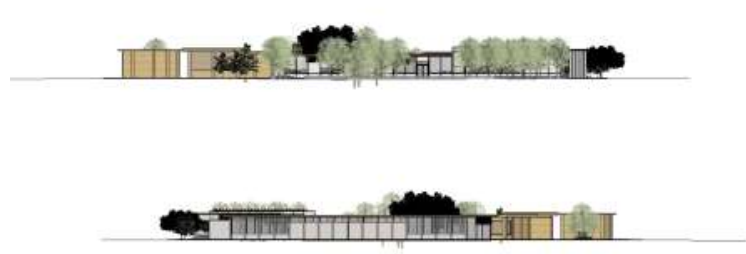

Gambar 10. Tampak Depan dan Samping Kawasan

Sumber: Analisis Pribadi (2020) 

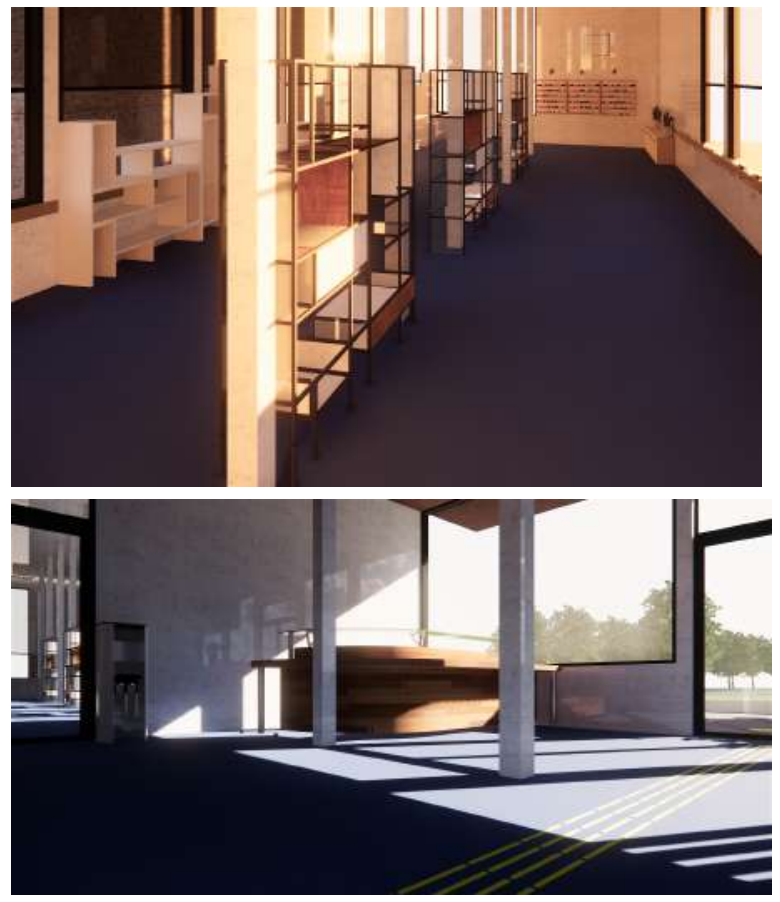

Gambar 11. Perpektif Interior Sumber: Analisi Pribadi (2020)
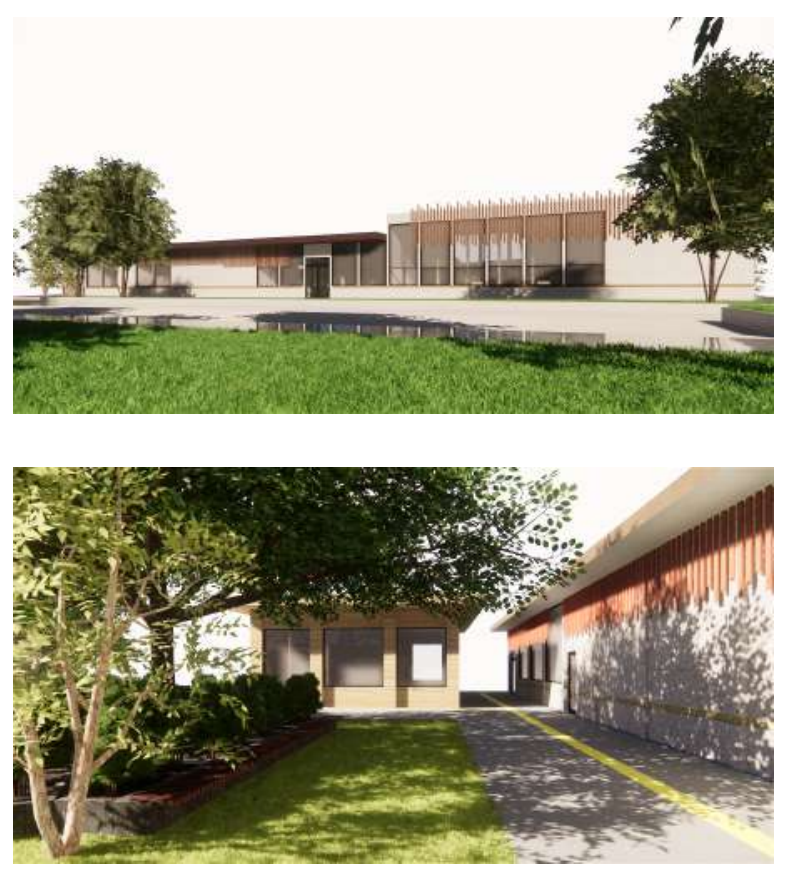

Gambar 12. Perspektif Eksterior Sumber: Analisis Pribadi (2020)

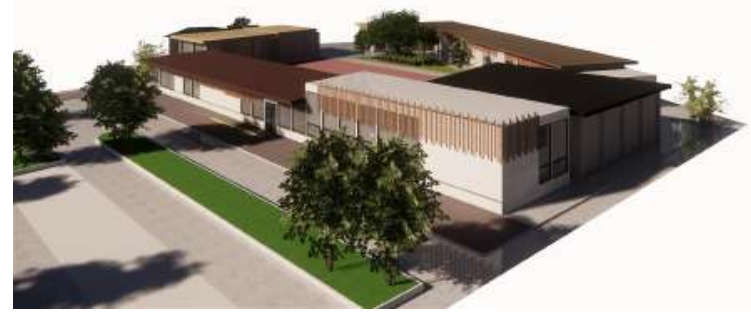

Gambar 13. Perspektif Mata Burung Sumber: Analisis Pribadi (2020)

\section{KESIMPULAN}

Ada banyak faktor yang berperan guna memaksimalkan ruang, bentuk dan sumber daya alam yang diharapkan dapat menjadi wadah untuk pengembangan SDM, pengembangan diri ini nantinya akan menjadi cikal bakal pengembangan kemampuan dari skala kecil menjadi lebih besar dimana pengguna diharapkan dapat berdiri sendiri.

Penyelesaian masalah menggunakan prinsip-prinsip aksesibilitas dan menggunakan metode perancangan orientasi dan mobilitas yang berfokus pada empat poin di antara lainnya, landmark, clue, compass direction dan measurement yang diaplikasikan pada setiap sisi ruang, setiap sisi bangunan baik area luar maupun dalam kawasan. Hal ini kemudian menghasilkan output analisis yang membuat kawasan dibagi menjadi tiga zonasi yaitu zonasi utama yang berisi Area Pengembangan SDM, Open Space, dan Sekretariat, lalu zona penunjang yang berisi Lobby di area depan kawasan, lalu Aula untuk kegiatan organisasi dan non organisasi, juga Area Display untuk hasil kerajinan penyandang, terakhir zonasi pendukung yang berisi Area Parkir, Servis dan Toilet.

Pusat Komunitas ini tidak hanya tertutup untuk pengguna, namun terbuka 
bagi seluruh penyandang tunanetra di Kota

Banjarmasin, juga terbuka bagi aktivis-aktivis maupun pemerintahan yang berencana melakukan kerjasama antara kedua pihak maupun lebih.

\section{DAFTAR PUSTAKA}

Referensi Buku dan Jurnal

Ching, F. D. (1996). Arsitektur Bentuk, Ruang, dan Tatanan. Surabaya: Erlangga.

Setiawan, Haryadi B. (2014). Arsitektur, Lingkungan dan Perilaku

\section{Website}

Badan Pusat Statistik (BPS). (2012). Data Susenas 